\title{
Ulusal Basın Ekseninde Atatürk Dönemi Öğrenci Hareketleri: Razgrad Hadisesi Örneği
}

\author{
DOI: $10.26466 /$ opus. 844644
}

$*$

\section{Neslihan Altuncuoğlu*}

* Dr. Öğr. Üyesi, Erciyes Üniversitesi, Edebiyat Fakültesi, Kayseri Türkiye

Öz

\author{
E-Posta: altuncuoglu@erciyes.edu.tr ORCID: 0000-0002-3244-5077
}

Sürekli olarak politikanın içinde yer alan gençliğin siyasal eylemleri, birinci Meşrutiyet öncesine kadar götürülebilmektedir. Sonraları meşruti bir yönetimi tekrar kurmak amacıyla oluşturulan ve içinde bulundurduğu gençlerin fazlalı̆̆ından dolayı Genç Türk Hareketi adını alan İttihat ve Terakki örgütünde de hep ön saflarda yer almışlardır. Gençlik Milli Mücadele döneminde vatanperver tutumuyla, Cumhuriyet döneminde ise özellikle örgütlü hareketleriyle adından sıklkla söz ettirmiştir. 1933 yılında yaşanan, Bulgaristan'da Müslüman Türklerin yoğun olarak yaşadığı bir bölge olan Razgrad Kasabasındaki Türk mezarlığına,milliyetçi Bulgar kuruluşları mensuplarınca saldırılıp tahrip edilmesi hadisesi Bulgaristan'da yaşayan Türkleri ve Türkiye kamuoyunu oldukça etkilemiş ve gündemi uzun süre meşgul etmiştir. Hadisenin üstüne giden Türk basını, konuyla ilgili çok hassas davranmış bu anlamda kamuoyunu bilgilendirmeye çalışmıştır.Milli Türk Talebe Birliği, özellikle Razgrad olayın protesto eyleminde büyük rol almıştır. Talebe Birliği idare Heyeti ve bazı talebe Cemiyetleri idare heyetleri azaları miting yapmak istemiş fakat bu teşebbüsleri reddedilmiştir. Tüm karşı çıkışlara rağmen hassas ve heyecanl gençlerin iştirakiyle oluşan kalabalık bir kafile ile büyük bir miting yapılmıştır.Bu çalışma da, yaşanan hadise, oluşan kamuoyu tepkisi, olayın perde arkası ve sonuçları dönemin ulusal basını ekseninde değerlendirilecektir. Araştırma yapılırken Cumhurbaşkanlığı Devlet Arşivi'nde bulunan belgeler, dönem gazeteleri ve basılı diğer kaynaklardan yararlanılmıştır.

Anahtar Kelimeler: Atatürk, Razgrad, Gençlik, Basın, Milli Türk Talebe Birliği 


\title{
Ataturk Period Student Movements On The National Press: The Razgrat Event
}

\begin{abstract}
The youth has always been the part, which has shown awareness to the problems, occurred within the society. It is possible to take back the political actions of the youth up to prior to the first constitutional era. The youth, which was always in the front lines of the organization, that had been formed to establish a constitutional administration and called as "Genc Turkler", due to the majority of young people amongst its members, has his name frequently mentioned with its mission during the war of independence. The youth was always been in the front lines within the republic period, particularly with the organized actions at the point of building a state and set forth supporting actions and expressions in this context. On April 1933 nationalist Bulgarian organizations were attacked and destroyed the Turkish graveyard in the Razgrad Township, which is a region where Bulgarian Muslim Turks lived , has greatly influenced Turks and Turkish public opinion in Bulgaria and kept the agenda busy for a long time. The Turkish press, who is closely interested in the incident, has been very sensitive about the issue and has tried to inform the public in this sense. When this event was heard in Turkey the press and the leadership of the Turkish National Student Union organized protests an meetings. The Turkish Nation condemned this event. The national sensitivity in this case increased. This event has caused a great reaction among the Turkish youth.This event has an important role in the public reaction and behind the scenes. In this report, the reasons and consequences of the Razgrad event will be assessed on the basis of the periodical national press. The documents in the Presidency State Archive, newspapers from the period and other printed sources were utilized in this the process of this study.
\end{abstract}

Keywords: Ataturk, Razgrad, Youth, Press, Turkish National Student Union. 


\section{Giriş}

Türkiye, Lozan Antlaşmasından hemen sonra Balkan Devletleri ile uzun süreden beri kesilmiş olan münasebetlerini yeniden kurmak için harekete geçmiştir. 1930'lu yıllarda, komşularıyla güven ve dayanışma içinde yaşayabilmeyi hedeflemiş önce Yunanistan, Yugoslavya ve Romanya ile 1934 Balkan Paktı'nı, sonra da Ortadoğu'da Irak, İran ve Afganistan ile 1937 Sadabat Paktı'nı gerçekleştirmiştir (Soysal, 1999, s.1445).

Balkan Birliği zincirinin en zaylf halkası Bulgaristan olmuştur. Bulgaristan'ın komşularından toprak istekleri vardır. Bükreş'te 23-26 Ekim 1932'de toplanan konferansta bu isteklerini azınlıkların haklarını korumak prensibinin arkasına saklayarak ve bu haklar korunmadıkça, Birliğin kurulmasında ehemmiyetli bir adım teşkil edecek olan paktı imzalamayacaklarını bildirmişlerdir. Bu dönemde, Bulgaristan'ın revizyonist emelleriyle komşularının statükocu politikaları açık olarak çarpışmaktaydı ( Esmer,1953, s.212). Bulgaristan, Birinci Dünya Savaşından sonra imzaladığı Neuilly Antlaşmasını kendi lehine değiştirmek istediği için, bütün ssrarlara rağmen bu ittifak sisteminin dışında kalmayı tercih etmiştir. Bulgaristan'ın bu davranışı karşısında Balkan Devletleri bu iki şıktan birini tercih etmek durumunda kalmışlardır: Balkan Paktı́ndan vazgeçmek ya da Bulgaristan'ı dışarıda bırakan bir Pakt imzalayarak Bulgaristan'ın sonradan katılmasını beklemek. Balkan Devletleri ikinci yolu seçmişlerdir (Gönlübol ve Sar, 1963, s.99). Türkiye, Balkanlarda Bulgaristan'ı da Balkan Birliği'ne alarak yaklaşmakta olan II. Dünya Savaşı'nın dışında kalmayı amaçlamıştır. Ancak Bulgaristan'ın izlediği revizyonist politika nedeniyle bunda başarılı olunamayacaktır ( Ağca,2014,s.113).

Pakt'ın gerçekleşmesi için Türk Devlet adamlarının gayretleri Bulgar basınında Türkiye aleyhinde yayınlara sebep olmuştur. 1934 yılının Şubat ayı başında Türkiye, Yunanistan, Yugoslavya ve Romanya Dışişleri Bakanları Belgrat'ta toplanmışlar ve Balkan Antantı'nın tasarısını hazırlamışlardır. Bu tasarının 9 Şubat 1934 tarihinde Atina'da imzalanması ile Balkan Antantı kurulmuştur. Bulgaristan antantın dışında kalmıştır (Gönlübol ve Sar, 1963, s.100). Türkiye Balkan Antantı'na giden yolda böylesine çaba gösterirken, Bulgaristan, Türk azınlığa karşı yürüttüğü baskıları artırmış, 1930'lu yıllarda Türk okulları kapatılmaya başlanmış veya bu okulları resmi Bulgar okullarına çevirmişlerdir. Bazı yörelerde ki Türk çocukları ya hiç okula gideme- 
miş ya da Bulgar okullarında Bulgarca okumak zorunda kalmışlardır (Şimşir, 1986, s.141).

10 Mayıs 1933 günü, Türkiye Dış işleri Bakan vekili Şükrü Kaya, Ankara'daki Bulgar elçisine 12 maddelik bir memorandum vermiştir. Bulgaristan Türk azınlığına yapılan baskıları madde madde Bulgar elçisinin dikkatine sunmuştur ( Şimşir, 1986, s.149).

Türkiye'nin Varna Konsolosluğundan gelen 07.05.1933 tarihli raporda şu ifadeler yer almaktadır:

"Son aylarda Bulgar milli duygusu çok beslenmektedir. Bulgarların milli duygusunu tahrik etmek mutlaka Türk düssmanlığından bahsetmek demektir. Kışkırtılan gen Bulgarlar mutlak suretle hedef olarak kendilerine pek kolaylıkla masum Türk yurttaşlarımızı ve onların mukaddesatını görmektedir. Bu gibi hakaret ve tecavüzler herhalde tevali edecektir. Her ne pahasına olursa olsun bu milyona yakın yurttaşlarımızın bir an evvel Bulgaristan'dan Trakya'ya veya Anadolu'ya nakledilmesinin gün geçtikçe bir zaruret halini aldığ1 mütalaasında bulunduğumu arzeylerim" (BCA, 03010241 627 26, 07.05.1933)

Yukarıdaki raporda belirtildiği gibi Türk yurttaşlarımıza yapılan haksızlıklar neticesinde bu topraklardan iltica eden ve Türk vatandaşlı̆̆ına alınan çok sayıda yurttaşlarımız olmuştur (BCA, 0301801023636 8, BCA, 03018 010023741 9).

19 Mayıs 1934 tarihinde Bulgaristan'da bir hükümet darbesi oldu. Bulgaristan, gitgide sertleşen faşist bir diktatörlükle yönetilmeye başlandı. Bulgar faşist diktatörlügü̈, Türk azınlığın ve Türk okullarının üzerine kâbus gibi çöktü. Türkçe eğitim veren Türk okullarının sayısı günden güne azalıyor, yarıya, üçte bire, dörtte bire düşüyordu. Bu azalma göçler yüzünden değil, Türk okullarının kapatılması veya Bulgarlaştırılması yüzünden olmuştu ( Şimşir, 1986, s.149). Türk hükümeti, Türkiye'nin Sofya Elçiliğinden gönderilen raporlar vasıtasıyla Türk azınlı̆̆a yapılan baskı ve haksızlıkları yakından takip etmiştir (BCA, 0301801023363 ).

Razgrad Olayı öncesinde, 15 Nisan'da Cumhurbaşkanı Gazi Mustafa Kemal Paşa, yeni Bulgar Sefiri M. Antonov'u Çankaya Köşkünde kabul ederek; "Milletlerimizin birbirlerine yürekten duygularla yaklaşmaları menfaatlerine en uygun olanıdır" şeklinde konuşmuşlardır (Vakit, 1933, s.2). Antanov'da yabancı gazetelere verdiği demeçlerde; " Türk dostluğunun muhafazası yolunda çalışacağını, her iki tarafında hüsnü niyeti sayesinde ihtilafl hiçbir mese- 
le kalmayacağını" ifade etmiştir (BCA, 0301000241627 17) . Bu iyi niyet dileklerinden kısa bir süre sonra Razgrad hadisesi yaşanmış, Bulgaristan devlet adamlarının düşünceleriyle Bulgarların düşünceleri arasında bir tutarlılık olmadığı gözler önüne serilmiştir.

Bulgaristan'ın tutumu Türk gençliğini de etkilemiştir.1933 yılında gençlik hareketleri hız kazanmış ve faaliyetleri Milli Türk Talebe Birliğince yönetilmiştir. MTTB Genel Başkanlığı yapmış önemli isimlerden biri olan Burhaneddin Kayhan (MTTB)'nin 4 Aralık 1916'da kurulduğunu ifade etmektedir. Ona göre MTTB'nin kuruluş yıllarındaki asıl amacı, "milli kurtuluşa" fiilen katılarak, Türkiye'nin düşmanları tarafından ortadan kaldırılma planlarına karşı durmak ve gençleri varoluş savaşına aktif olarak hazırlamaktadır ( Duman ve Yorgancilar, 2008, s.35).

Razgrad'daki Türk Mezarlığı'nın, "Vatan Koruyucuları" isimli Bulgar kuruluşu mensuplarınca tahrip edilmesi üzerine, İstanbul'da Milli Türk Talebe Birliğgi'ne bağlı öğrenciler tarafından, hükümetin izin vermemesine rağmen bir miting düzenlenmiştir ( Yeni Türk Ansiklopedisi, 1985,s.3195) On bine yakın gösterici kalabalı̆̆ı güvenlik güçleri tarafından dağıtılmaya çalışırken, bir grup öğrenci Bulgar mezarlığına girerek çelenk bıraktı. Gösteriler nedeniyle gözaltına alınan 80 öğrenciden 23 'ü tutuklandı. Altı gün sonra serbest bırakılan öğrenciler, yargılanmaları sürerken çıkarılan genel aftan yararlandılar (Cumhuriyet Ansiklopedisi, 2005, s.209). Bu çalışma da, yaşanan hadise, oluşan kamuoyu tepkisi, olayın perde arkası ve sonuçları dönemin ulusal basını ekseninde değerlendirilecektir.

\section{Yöntem}

Tarama modeliyle gerçekleştirilen bu araştırma da, Cumhuriyet döneminde gençliğin, ulus-devlet inşası noktasında yürüttüğü faaliyetleriyle, örgütlü hareketleriyle, destekleyici söylem ve eylemleriyle toplumunun fikir, ideal ve ruh yapısını yansıttığı gerçeği, Razgrad Hadisesi örneği ekseninde betimsel bir araştırmayla ortaya konulmuştur. Bu araştırmada nitel veri toplama tekniklerinden biri olan doküman incelemesi kullanılmış ve elde edilen veriler betimsel analiz tekniğiyle incelenmiş, kaynaklarından alıntılar yapmak suretiyle çalışmanın güvenirliliği artırıldığı gibi verilerin okuyucuların anlayabileceği ve kullanabilecekleri bir şekilde düzenlenmesi de sağlanmıştır. Araştırmada veri toplama aracı olarak incelemeye alınan veriler; 
T.C. Cumhurbaşkanlığı Devlet Arşivleri Başkanlığ 1 Cumhuriyet Arşivi fonlarında yer alan kaynaklar, dönemin gazeteleri, konu ile ilgili telif eserler, lisansüstü tezlerden temin edilmiştir. Eldeki veriler anlam bütünlügü açısından tasnif edilerek çalışma şekillendirilmiştir.

\section{Bulgular}

Sürekli olarak politikanın içinde yer alan gençliğin siyasal eylemleri, birinci Meşrutiyet öncesine kadar götürülebilmektedir. Sonraları meşruti bir yönetimi tekrar kurmak amacıyla oluşturulan ve içinde bulundurduğu gençlerin fazlalığından dolayı Genç Türk Hareketi adını alan İttihat ve Terakki örgütünde de hep ön saflarda yer almıştır. Gençlik Milli Mücadele döneminde vatanperver tutumuyla, Cumhuriyet döneminde ise özellikle örgütlü hareketleriyle adından sıklıkla söz ettirmiştir ( Şahin, 1992, s.15 ) .

1933 yılı gençlik örgütlenmeleri bakımından hareketli bir yıl olmuştur. Bu dönemde milliyetçi Türk gençlik hareketleri yoğunlaşmış ve bu milliyetçi çalışmalar Milli Türk Talebe Birliği'nce yönetilmiştir. Nitekim 3 Mart 1933 günü İstanbul Halkevi'de yapılan bir gençlik toplantısında konuşan Milli Türk Talabe Birliği Başkanı Tevfik İleri Bey, dil konusunu ele almış ve toplantı sonunda Türkiye'de sadece Türkçe'nin hâkim olması için gereken her türlü çabanın gösterilmesi ve bir miting yapılarak azınlıktaki vatandaşlarımızın uyarılması kararlaştırılmıştır. Milli Türk Talebe Birliği, 10 Mart 1932 deki toplantısında bir "Gençlik Marşı " hazırlanmasına ve tüm öğrencilerin bir tip kasket giymesine karar vermiştir. 16 Mart 1933'de yapılan Şehitleri Anma törenine, Türk Gençliği toplu halde katılmış ve Milli Türk Talebe Birliği Başkanı Tevfik Bey, milli duyguları coşturan bir konuşma yapmıştır ( Goloğlu, 2009, s. 102) . 1933 yılında İstanbul Üniversitesi Konferans Salonu'nda yapılan bir toplantıda yine Birlik Başkanı Tevfik Bey heyecanlı bir konuşma yapmış ve dil seferberliği yapılması kararlaştırılmış, Türk gençliğinin Anadolu'yu tanıması için geziler düzenleneceği belirtilmiştir. Ulusal duyguların geliştirilmesi için ulusal günlerin anlam ve öneminin anlatılması, büyük kişilerin ve özellikle büyük şehitlerin unutulmamasına çalışılması, Türk gençliğinin, Türk milletine layık olarak yetişmesine uğraşılması kararlaştırılmış ve bu kararlar bir basın toplantısında, Birlik Başkanı Tevfik Bey tarafından açklanmıştır (Goloğlu, 2009, s. 103). Birlik, milliyetçilik duygularını gençlik kesiminde yüksek kılmak, pekiştirmek amacındaydı. Amb- 
lem olarak "Bozkurt"u seçmişlerdi. O dönemde pulların, kâğıt paraların üzerinde de "Bozkurt" resmi bulunmaktaydı. Güçlendirilmeye çalışılan "Ulus devlet" anlayışının bir işareti olarak kabul ediliyordu ( Çavdar, 1995, s.322). Bu amblemin üniversitelilerin giydiği kasketlerde de yer almasına karar vererek, aynı yıl Birlik adlı bir gazete yayımlamaya başladılar ( Kabacalı, 1992, s.79). Birlik Gazetesinin ilk sayısı 2 Temmuz 1933'de çıkartılmış ve 14 sayı yayınlanmıştır. Gençliğin milli duygularına tercüman olan bu mecmuada bütün memleket meseleleri dile getirilmiştir (Aksoy, 1977, s.39).

Milli Türk Talebe Birliği, özellikle Razgrad olayını protesto eyleminde büyük bir rol almıştır. MTTB'de Tevfik İleri'nin kişiliğinin ve fikirlerinin baskın bir yönü vardır ( Duman ve Yorgancılar, 2008, s.37). Tevfik İleri, Yüksek Mühendislik Okulu'nda okuduğu yıllarda Teknik Üniversite Talebe Cemiyeti ve Milli Türk Talebe Birliği başkanı olarak İstanbul'daki öğrencilerin milliyetçilik hareketlerine önderlik etmiştir. Aynı hisle; Bulgaristan'ın Razgard Kasabası'nda Türk ve Müslüman mezarlığının Bulgarlar ve bilhassa Bulgar gençleri tarafından tahrib edilip, Türklerin kemiklerinin mezarlardan çıkarılarak, yaşayan insanlara duyulan kinin, yıllarca evvel hayatını kaybedenlerden alınmak istenmesi karşısında galeyana gelen gençlere, İstanbul'daki Bulgar mezarlığına çelenk koydurarak asil bir karşılık verenlerin başında bulunmuştur ( Her Yönüyle Tevfik İleri, 1995, s.5).

17 Nisan 1933 pazartesi günü, Sofya'dan şu haber sızıp gelmiştir. Deliormanın göbeği olan Razgrad kasabasındaki Türk Mezarlığı organize edilmiş Bulgar kalabalı̆̆ tarafından tahrip edilmiştir ( Vakit, 1933, 18, Nisan, s.1). İlk olarak mezarlık bekçisinin kulübesini yakmışlar, tel örgüleri keserek mezarlı̆a girmişler, bütün taşları yıkmışlar, mezarları açmışlar ve yüz elli kadar cenazenin kemiklerini dışarı çıkartmışlardır. Razgrad hadisesi, Türkiye'nin Varna Konsolosluğundan gelen 07.05.1933 tarihli raporda şu şekilde ifade edilmektedir:

“14-15 Nisan Cuma gecesi, Hz. İsa'nın öldüğü gece, karanlıkta Razgrad Türk mezarlığına yerli Bulgarlar tarafından pek çirkin bir taarruz yapıldığı haber alındı. Münasip suretle yapılan tahkikat neticesinde bu taarruzu yapanların Rodna Zoştita cemiyetine mensup olan müfrit milliyetperverler olduğu anlaşıldı. Akşamdan kluplerinde içtima eden bu müfrit milliyetperverlerin yapacakları işi evvelden tasarladıkları, evlerden kazmalarla, küreklerin toplandığı ve grup halinde mezarlığa gittikleri, evvele mezarlığın tel örgüsü kesilerek kabristana girildiği ve kabristan bekçisinin evi yakıldığ 1 ve 
bu hareketi müteakip iki yüz kadar bulgarın mezarlığa dağılarak ellerindeki balta, kazma ve küreklerle mezar taşlarını kırıp geçirdikleri, mezarların tahrip ve telvis edildiği, hatta ölülerden birkaçının bile mezardan çıarıldığı ve bu esnada bir de kamyonun çalıştı̆̆ öğrenildi. Kayda şayan olan nokta: Vaki olan şikayetler üzerine tevkif edilen Bulgarların tahliyesi için Razgrad Bulgar halkının nümayiş yapması keyfiyetidir. Mahalli gazetelerin yazıları ile de hadisenin dehşeti itiraf edilmektedir" (BCA, 03010241627 26).

Bu taarruzdan dehşete düşen halk, Sofya'daki resmi makamlara telgraflar çekerek müracaat etmişlerdir (Vakit, 1933, 19, Nisan, s.9) Anadolu Ajansı Sofya muhabirine, Bulgaristan İçişleri Bakanlığı, vak'ayı tasdik etmiş ve şöyle devam etmiştir:

Razgrad belediye meclisi evvelce bir Türk mezarlığının belediyeye maledilmesine ve Türklere başka bir mezarlık yeri gösterilmesine karar vermiş. Fakat Razgrad Müslümanları ölülerini yine eski mezarlığa gömmeye devam etmişlerdir. Hadisenin, belediyenin kararını emrivaki yapmak isteyen ve mezarları sökerek yerine ağaç diken gençler tarafından bu sebepten dolayı gerçekleştirilmiş olduğunu söylemiştir. Polisin müdahale ettiği fakat klise inzibatiyle meşgul olduğu için geç kaldığı belirtilmiştir (Vakit, 1933,19, Nisan, s.9)

Bulgaristan'ın Razgrad kasabasında ki tecavüz hadisesi halk üzerinde özellikle Üniversite gençliği üzerinde çok derin tesirler yaratmıştır( Cumhuriyet, 1933, 19, Nisan s.1). Tevfik İleri, hadisenin ardından gerçekleşen gençlik örgütlenmesini şu şekilde anlatmıştır:

"Sabaha karşı hademe beni uyandırdı. "Seni, beş-altı genç görmek istiyor" dedi. Gelenler tıbbiyeden altı kadar genç arkadaştı. Bunlar, "Razgrad hadisesine artık bir cevap vermek zamanı gelmiştir" diyerek söze başladılar. Onların fikirleri şu idi: "Gençliğin beklemeğe tahammülü kalmamıştır. Bu iş derhal yapılmalıdır." Netice itibariyle birlik idare heyetinde bulunan okulumuzdaki arkadaşlardan birinin de iştiraki ile altı arkadaş o sabah akşam saat 5'te Pangaltı'da Bulgar Konsoloshonesi önünde toplanmak ve oradan Bulgar mezarlığına gitmek ve bütün medeni dünyanın önünde Bulgar mezarlığına çiçek serpmek ve bu suretle dünyaya Türk'ün mert, âlicenap ve insan varlığını bir kere daha duyurmak kararını verdik. Sabah saat 8 'de karar veriyoruz. Akşam 17'de toplanacağız. Bu nasıl mümkün olacak. Halbuki kısa bir zamanda 3-4 bin kişiyi bir araya toplayan varlık sadece, ruhlarımızı saran milli duygu ve heyecanlar ve bizi milli davalardan birbirimize 
sımsıkı bağlayan bağlardı. Pangaltı'ya geldiğimiz zaman, grup grup gençlerin dolaşmakta olduklarını ve hadiseden haber alan polislerin gelmiş bulunduklarını gördük. Meğer saat 17 olur olmaz talebe, birden Konsoloshane önünde toplanarak binanın içerisine girmeğe teşebbüs etmişler. Polisler binayı tutmuş, talebe ile polis mücadele haline geçmiştir. İşte bu sırada ben vak'a yerine geldim. Tesadüfen orada bulunan bir otomobilin üstüne çıkarak gençleri etrafımda topladım. Günün manasını, yapılacak işin ne olduğunu anlattım ve kısa zamanda binlerce genci, önlerinde bayraklar dalgalanarak konsoloshanenin önünden mezarlığa doğru hareket ettirdim. Öyle zannediyorum ki tevkifimizden beş gün sonra tahliyemiz de Atatürk'ün müdahalesiyle oldu" (Aksoy,1977,s.32).

Bulgar Elçisi, Ankara da hadiseyi kabul etmiş. Fakat cereyan şeklini başka türlü izah ederek, hadisenin vaki olduğu fakat Türklere karşı bir hareket olmadığını belirtmiştir. Razgrad'ta belediyenin bir park yapmak istediği, bu parkın yapılacağı saha yanında Türk mezarlığı da bulunduğunu, mezarlığın alelusul istimlâkine karar verildiği fakat mahalli Türk halkından gelen bazı mukavemetler dolayısıyla işlerin müşkülatla ilerlediğini, istimlâk muamelesinin ağır gittiğini gören bazı müfrit anasırın bu işi cebren halletmeyi kendilerince en kestirme yol bilerek hadiseyi meydana getirdiğini ifade etmiştir (Cumhuriyet, 1933,20, Nisan s.1).

Bulgar Başbakanı Gospodin Muşanof da; "Bu hareket ahalinin dini hislerine karşı yapılmış bir taarruz değildir. Esasen mücrimlerin adliyeye teslimi için icabeden emirleri verdim" (Taylak, 1969,s.126)."Belediyeyi protesto etmekten başka bir hedefleri olmayan bazı gençlerin düşünmeden yaptıkları budalaca bir hareket olduğu aşikârdır" diyordu (Hâkimiyeti Milliye, 1933, 21, Nisan, s.1).

Razgrad hadisesine dair meclis müzakerelerinde Başbakan Muşanof, Türk matbuatının aktardığı istihbaratları mübalağalı bulduğunu belirterek şöyle devam etmiştir: "Şimdi bu hadise tasfiye olunmuştur. Türk ve Bulgar milletleri arasindaki samimi dostluk bu gibi hadiselerle kararmaz. Maamafih böyle hadiselere ileride mani olmak lazımdır" (Hâkimiyeti Milliye, 1933,26, Nisan, s.1 ). Muşanof benzer cümleleri Bulgar meclisinde Hariciye bütçesinin müzakeresi münasebetiyle yaptığı konuşmasında dile getirmiştir. Bulgaristan'ın komşu devletlerle olan ilişkileri hakkında izahat vermiş, Sosyalist gruplara mensup vekillerden bazıları Muşanof'u tenkit eder sözler söylemişlerdir. Muşanof cevabında: 
Türkiye ile dostluk ve anlaşmalara bağlıyı. Münasebetimiz hissiyat ve menafimizin emrettiği şekilde çok samimidir. Hareketlerinin hesabını veremeyen güya Bulgar vatanperveri geçinen birtakım bedbahtların eseri olan ve vukuu istemeyen Razgrad Hadisesi çok istismar edilmiştir. Fakat bütün bunlar dostluğumuza zarar vermemiştir. Biz bu dostluk için mümkün olan her şeyi yaptık. Seleflerimiz tarafından bize bırakılan dostluk vaziyetini muhafaza etmekle kalmayıp onu artırdık demiştir ( BCA. 3010241630 2) .

Bulgar parlamentosunda yapılan bir başka görüşmede ise Sosyalist mebus Pastuhof, Razgrad Olayı́nı kimin yaptı̆̆ını bilmek istediklerini, TürkBulgar dostluğunu ihlal edecek bu gibi hadiselerin tekrar etmemesi için ne gibi tedbirler alındığını sormuştur. Sonrasında, Nasyonal Liberal grubundan milletvekili Açkof söz almış ve bu olayın Türk matbuatına yanlış aksettirildiğini söylemiştir (Cumhuriyet, 1933,28, Nisan, s. 1).

Peyami Safa "Bu ne Demek?" başlığıyla kaleme aldığı yazısında Başbakan Muşanof'un konuşmalarının tezatlarla dolu olduğunu ifade etmiş ve şöyle devam etmiştir:

"Bulgar Başbakan, Türk gazetecilerini yalancllıkla itham ediyor. Bir taraftanda Bulgaristan'da kanunun hudutları dışına çıkan milliyetçi teşekküller olduğunu itiraf ediyor. Mademki Bulgar kanunlarını tanımayan bir takım çeteler vardır. Mademki Razgrad mezarlığına şu ya da bu şekilde taarruz etmişlerdir ve mademki Bulgar hükümeti bunları öğleyin yakalayıp akşamüstü bırakmıştır, Türk matbuatının yalancılığı nerede kal1yor"(Cumhuriyet, 1933, 29, Nisan, s.2).

Bulgar Dâhiliye Nazırı Razgrad hadisesi sonrası Türk ekalliyetiyle ilgili gazetecilere verdiği beyanatında, Türk ekalliyetinin baskı ve zorlama görmediğinden, herkesin işi ile meşgul olduğundan ve Türklerle Bulgarların pekiyi geçinmekte bulunduklarından bahsetmiş ve bizzat Türk ekalliyetinin tazyik edildikleri hakkında neşredilen yanlış haberlerden nefret duyduklarını ilave etmiştir. Dâhiliye nazırının bu beyanatı, Türk hükümeti tarafından hoş karşılanmamış, evvelce yapılmış vukuatı ret ve inkâr etmesi itibariyle Türk ekalliyetine fenalık yapan, onu ezen bulgarları adeta teşvik edici mahiyette bulunarak, son vaziyeti de anlaması itibariyle gerçekçi bulunmamıştır (BCA, 03010242635 17).

Razgrad hadisesi yüzünden Talebe Birliği idare Heyeti ve bazı talebe Cemiyetleri idare heyetleri azaları nümayiş yapmak istemiş fakat bu teşebbüsler reddedilmiştir (Milliyet, 1933, s.1). Hükümet, basında yer alan Türk 
mezarlarının kasıtlı olarak tahrip edildiği haberlerine sıcak bakmamıştır. Bu yüzden MTTB'li gençlerin olayla ilgili geniş katılımlı bir mitingi düzenlemelerinin iyi olmayacağına inanmışlardır. Bundan dolayı CHP İstanbul Temsilcisi Cevdet Kerim, MTTB yöneticilerini çağırarak onlarla bir ön görüşme yapmış, politik bir mesele çıkabilir, bir hareket yapmayın, birliği kapatırız demiştir. İktidar partisi, komşusu Bulgaristan ile olan ilişkilerin bozulmasını istememekte, Bulgarların Türk mezarlarını kasıtlı olarak tahrip ettiğine inanmamakta veya inanmak istememektedir (Duman ve Yorganc1lar, 2008,s.50).

İktidarın tüm karşı çıkışlara rağmen MTTB adeta kendi rüştünü ispat etmek istercesine ve bağımsız karar alıp uygulayabilme konumunda olduğunu göstermek amacıyla 20 Nisan 1933 tarihinde büyük bir kalabalık eşliğinde eylem yapmıştır( Duman ve Yorgancilar, 2008, s.51).

Hassas ve heyecanlı gençlerin iştirakiyle oluşan kalabalık bir kafile ile büyük bir nümayiş yapılmıştır (Son Posta, 1933, s.2). Saat 16.30'dan itibaren Maçka'daki Bulgar Konsolosluğu'nun önünde beşer onar kişilik talebe kafileleri toplanmaya başlamıştır. Kısa bir süre sonra sayı oldukça artmış, O civarda okullarından çıkan, bilhassa Şişli Terakki ve Feyziye Liseleri ve diğer okullardan talebeler de toplantıya iştirak etmişlerdir (Milliyet, 1933, s.2).

Bu sırada zabita nümayişçileri dağıtmakla meşgul olmuştur. Fakat gençlerin bir kısmı arka sokaklardan Bulgar mezarlığına gitmişlerdir. Jandarma zabitan ve efradl, polisler kendilerini mezarlığa sokmak istememişlerdir ( Akşam,1933, 21 Nisan, s. 1). Fakat gençler duvardan aşarak şapkalarını çıkarıp mezarlığa girmişlerdir. Burada Tevfik İleri Bey: “Arkadaşlar programımıza göre buradaki ölülerin mezarı üzerine getirdiğimiz çelenkleri koyacağız. Bütün hareketlerimizde bir kabristanda olduğumuzu unutmayalım" şeklinde bir konuşma yapmıştır (Son Posta,1933, s.9).

Aralarından bir genç; "Bizden insaniyet dersi alın. Biz ölülere hakaret değil, böyle hürmet ederiz" ifadeleriyle başlayan bir konuşma yapmıştır. Fakat Jandarma ve Polis kendilerini mezarlıktan dışarı çıkarmıştır. Kafile halinde dönülürken Pangaltı Karakolu önünde büyük bir zabıta kuvveti nümayiş̧̧ileri durdurmuştur. Zabıta memurları nümayişçilere dağılmalarını aksi takdirde cebir ve silâh kullanmak mecburiyetinde kalacaklarını bildirmişlerdir. Fakat nümayişçiler dağılmamakta 1srar etmişlerdir (Akşam,1933, s.1). Polis meçleriyle kitledeki Türk bayraklarının yırtılması sebebiyle, kitle polise saldırmış, polis yetersiz kalınca askerden yardım istemiştir. Bu sırada 
sayısız polis ve genç yaralanmıs, karakollar olayla ilgisi olsun olmasın güvenlik kuvvetlerince yakalananlarla dolmuştur ( Nesimi,2008, s.80).

Yetkili makamlar şu beyanatta bulunmuşlardır:

"Fenalığa fenalıkla cevap vermek doğru değildir. Türk gençliğinin asaletine ve nezahetine (kibarlı̆̆ına) şüphe yoktur. Gençliğimiz ne kadar dikkatli olursa olsun aralarına bir takım yabancı emellere hizmet edebilecek ve ne oldukları belirsiz insanların karışabilmesi ihtimalleri her zaman vardır. $\mathrm{Bu}$ gibi taşkın hareket hiç şüphesiz hükümetin siyasetine tamamıyla muhaliftir. Gençliğin bu hassasiyeti nezih bir tecelli olmakla beraber, Cumhuriyet hükümetin kararları haricindeki hareketler daima zararlı olur. Bunun için dünkü hadiseyi teessüre değer buluyoruz" ( Cumhuriyet, 1933, s.1).

Necmettin Sadık hadiseyle ilgili şunları vurgulamıştır:

“Bulgaristan' $n$ bir kasabasında her türlü insanlık ve medeniyet duygularından mahrum bazı terbiyesizlerin Türk Mezarlığına tecavüz etmeleri, memleketimizde derhal, büyük bir asabiyet uyandırdı. Gençlerin hassasiyetine hak vermemek mümkün değildir. Bilhassa, müessil bir hadiseye meydan verilmemiş olması, bilakis Bulgaristan'daki kaba harakete mukabil, insanlık ve nezaket dersi mahiyetinde bir hareketle mukabele edilmesi, Türk gençliğinin medeni ve siyasi rüştünü isbat eder" ( Akşam,1933, s.1).

Göstericilerden aralarında Talebe Birliği Başkanı Tevfik İleri'nin de bulunduğu 80 kişi tutuklanmıştır (Cumhuriyet, 1933, s.1). Tahkikat iki safhada ilerlemiştir. Birinci safhası bu nümayişe ön ayak olanlar, ikinci safhası da tezahüratın başından sonuna kadar ihtarlara, hatta fiili uyarılara karşı koyanlar hakkındadır (Vakit, 1933, s.1). Tecemmu kanununa muhalif hareket ettiklerinden dolayı haklarında takibat yapılan talebeden $60^{\prime} 1$ serbest birakılmış, 20 kadar talebinin ise salahiyetli hâkim huzuruna çıkarılmasına karar verilmiştir (Cumhuriyet, 1933, s.1).

Türkiye Dışşsleri Bakanı Tevfik Rüştü Bey, Cenevre'ye giderken Filibede Başbakan M. Muşanof ile görüşmüştür. Razgrad Türk Mezarlığı hadisesi hakkında sorulan suallere Tevfik Rüştü Bey şu suretle cevap vermiştir: "Hadise halledilmiştir. Fakat bu vaka gösteriyor ki: Her iki hükümet kendi topraklarnnda komşu memleket aleyhine yapilan veya yapilması muhtemel olan propaganda ile mücadele etmek mecburiyetindedir". Tevfik Rüştü Bey iki memleket arasındaki dostluk bağlarını daha ziyade sıklaştırmaya çalıştığını söyleyerek sözlerini bitirmiştir (Akşam, 1933, s.1). 
Başbakan M. Muşanof gazetecilere beyanatında Razgrad hadisesinin, Tevfik Rüştü Bey'le Filibe istasyonunda yaptığı mülakattan sonra kapanmış telakki ettğini, Türk ve Bulgar milletleri arasındaki samimi dostluğun bu gibi hadiselerle kararmayacağını, böyle hadiselere ileride mani olmak lazım geldiğini ifade etmiştir (Cumhuriyet, 1933, s.1).

Tevfik Rüştü Bey, Bulgar topraklarından geçmesi esnasında, kendilerini ziyaretlerinden dolayı Bulgar Kralına ve Başbakan Muşanof'a birer teşekkür telgrafı göndermiştir. Sofya Büyükelçiliği'nden alınan rapordan anlaşıldığı üzere, Tevfik Rüştü Bey'in yanına Başbakan Muşanof ile birlikte Bulgaristan Kralı da gelmiştir (BCA, 03010241630 13).

$\mathrm{Bu}$ önemli olayla ilgili Bulgar basınında haberi duyuran Utro ve Zora gazeteleri, olayı Türk basınına duyurmuş olan Deliorman gazetesi sahibi Mahmut Necmettin (Deliorman), Karadeniz gazetesi sahibi Arif Necip (Kaskatı) ve Anadolu Ajansı Balkanlar muhabiri Ali Naci Bey'i ve Türk basınını olayı abartmakla suçlamıştır(Ertürk, 2005, s.209). Bulgaristan'da çıkan Trakya gazetesinin 1 Haziran tarihli nüshasında, bugünkü şekilde Bulgaristan zararına bir Türk-Bulgar dostluğu olamayacağından ve Razgrad hadisesinden dolayı bölge kaymakamını lüzumsuz olarak memuriyetinin tahvil edildiğinden bahseden bir yazı kaleme alınmıştır (BCA, 030.10.241.630.8). Trakya gazetesinin 4 Mayıs 1933 tarihli nüshasında, İstanbul ve Razgrad'daki olaylar konu edilmiştir. Beş asırdan beri köle olan bir halkın Türk dostluğunu arzu etmeme hakkına sahip olduğu anlatılmıştır ( BCA, 030.10.241.629.2).

Bulgaristan'dan gelen haberler doğrultusunda, Mezarlığı yıkıma gelenlerin 350 den fazla olduğu ifade edilmiştir. Olayla ilgili tahkikata başlanmış, hadiseye önayak olanlardan 60 kişinin ifadesi alınarak, on bir kişi tutuklanmıştır (Cumhuriyet,1933, s.1).

Yunus Nadi köşe yazısında hadise hakkında şunları ifade etmiştir:

“Deliorman Türklerinin Bulgaristan'da pek çalışkan, namuslu ve cidden mert bir unsur olduğunu bilmemiz bu fena hadisedeki teessürlerimizin daha kuvvetli olmasına sebep olmaktadır. Şunu da ilave edelim ki dünyanın neresinde olursa olsun herhangi bir Türk'ün herhangi derecede teessüründen müteessir olmamız gayet doğal olmakla beraber eğer Razgrad'ta taarruza uğrayan mezarlık Türk Mezarlığı olmasaydı hadiseyi yine aynı kuvvet ve kanaatle böyle ret ve takbih eden bir lisan kullanırdık. Durup dururken kimin olursa olsun mezarlı̆gına taarruz etmekte elbette asil bir 
mana yoktur. Hadise yalnız insanlık noktasından bile fenadır. Ümit ediyoruz ki Bulgar hükümeti Bulgar milletinin şeref ve haysiyeti için gerekli olan bu kaba hareketi tamirde gecikmeyecektir" (Cumhuriyet, 1933, s.1).

Abidin Daver "İşte Bulgar Dostluğu" başlıklı köşe yazısında; "Vatan Muhafızı" Cemiyeti azasından olduğunu söyleyen İstanbul'da yaşayan Petrov isimli bir Bulgar' in mektubuna yer vermiştir:

“20.04.1933 tarihli nüshanızda" Gospodinlerin Türkler'e dost olup olmayacağını soruyorsunuz. Cevap! Siz bizi yani Bulgarları kendinize dost addediyorsanız çok aldanıyorsunuz. Çünkü 500 sene babalarımız, dedelerimiz Türk esareti altında yaşadılar. Onların çektikleri biz bütün gençlerin kalbinde kızıl kanla yazılıdır. Şimdiki Bulgar hükümet ricali Türkler'e dostmuş, kaç para eder! Bulgar milleti, Bulgar gençliği Türk'ün düşmanıdır, mekteplerimizde, tiyatrolarımızda, içtimalarımızda bunu okuduk, bunu dinledik, bunu biliriz. Türkler'in Bulgaristan da yeri yoktur başlarını alıp gitsinler.

Bu mektubu yazan Rodnozaştika Cemiyetinin İstanbul'da oturan azasından Gospadin Petrov'a teşekkür ederiz. Hiç olmazsa, doğruyu söyleyecek ve riyakârlık etmeyecek kadar mertlik gösteren bir Türk düşmanıdır. Esasen, senelerden beri, Türk düşmanlığı ile yetiştirilen Bulgar'ların dostluğundan hayır ummak zehirden şifa beklemek kabilinden bir şey olduğunu bilmiyor, değiliz. Bulgarlar arasındaki Türk düşmanlı̆̆ı, bugün değil, Umumi Harpte Bulgarları düşman çizmeleri altında ezilmekten kurtarmak için Dobruca ve Makedonya'ya beş Türk fırkası gönderdiğimiz zaman bile, apaçık kendini göstermişti. Kendilerine yardıma koşan ve bu uğurda binlercesi şehit düşen kahraman Türk askerine karşı her yerde husmetkâr bir tavır takınmışlardı. Bugünkü Türk düşmanlığı, Bunların senelerden beri aldıkları terbiyenin tabir neticesidir. Milliyetçi Bulgar gençliği Razgrad'taki Türk mezarlığında ölüleri mezarlarından çıkarıp atıyor, milliyetperver Türk gençliği, bu harekete Bulgar mezarlığına çelenk koymakla mukabele ediyor. Bugünkü vaziyette biz, Bulgar'ların dostluğuna değil, onlar bizim dostluğumuza muhtaçtır. Fakat mademki Bulgar'lar dostluğumuzu istemiyorlar. Zorla güzellikle olmadığı gibi dostluk ta olmaz, biz de onlara mertçesine uzattığımız eli çekeriz (Cumhuriyet, 1933 22, Nisan, s.1).

İstanbul Barosu avukatlarından Halil Yaver Bey, Bulgaristan ve Bulgarların memleketimiz hakkında ki maksatlarını anlatan“Bu Günkü Bulgaristan'da Türk Düşmanlığı" isimli küçük bir kitap yazmıştır. Halil Yaver 
Bey'in yazmış olduğu bu kitap hakkında Bulgar gazetelerin de çeşitli yazılar kaleme alınmıştır. Trakya Gazetesinde ki makalelerin birinde kitap için yazılan cevapta; "Az medeni Türklerin kendilerini Avrupa'dan kovanların Bulgarlar olduğunu unutmayacakları" ifade edilmiştir. Diğer bir makale de, Bulgarların Halil Yaver Bey'in zannettiğinden fazlasını yani Midye Enez hattını istemekte oldukları, Türklerin Bulgarlardan korktukları, Türklerin Balkanlara gelmeden evvel Bulgar ırkının Trakya'da muharebeler vermiş olduğu, Bulgarların Türk ırkından olmadıkları, vaktiyle bize uşaklık ettiklerini de saklamadıkları, sonra eski efendilerini nasıl yendiklerinin malum olduğunu, 1913'te palyaço pehlivanlıkla Türklerin Trakya'yı geri aldıkları ifadeleri yer almaktadır(BCA, 030. 10. 241. 627. 2).

Türkiye Cumhuriyeti Belgrat Büyükelçiliğinden alınan rapor da Bulgarların maksatların görme açısından önemlidir. Raporda yer alan; "Dost geçindiğimiz Bulgarlarm komşularından istedikleri arazi mey anında, altı asırdan beri Türk'ün ana vatanı olan Şarki Trakya'nın da bulunması Bulgarların aç gözlülü̈̆̈̈̈ne ve siyasi terbiye ve nezaketten mahrum olduklarna en bariz bir delildir" ifadeleri dikkat çekicidir( BCA, 030. 10. 241. 628. 9).

Bu olay İzmir gençliği arasında da akisler uyandırmıştır. İzmir Halkevinde bir toplantı yapılmış, İstanbul mitingi sırasında polisçe tutuklanmış olan İstanbullu gençlerin serbest bırakılması ricasında bulunmak üzere Atatürk'e ve devlet büyüklerine telgraflar gönderilmiştir ( Yazman,1984,s.399). Türk mezarlı̆̆ının tahrip edilmesi, sporcu gençliği de fevkalade müteessir etmiştir. Sporcular birkaç hafta sonra Sofya' da Türk - Bulgar milli takımları arasında yapılacak milli maçın bu çirkin olaydan sonra yapılamayacağını, Türk'ün mezarını yıkan, ölülerini tahkir ve tezyik eden bir memleket gençliğine dostça el uzatamayacaklarını söylemişlerdir ( Akşam, 1933, s.2).

İstanbul'da bulunmakta olan Bulgaristanlı Türkler de, Bulgaristan'daki vaka üzerine bütün gazeteleri ziyaret etmişler ve haklı teessürlerini ifade etmişlerdir, aynı zamanda Vali Muhittin Beyi de ziyaret ederek bir protesto mitingi yapmak için müsaade istemişlerdir ( Hâkimiyeti Milliye,1933, s.1).

Adana'da görev yapan öğretmenlerde, Razgrad'daki hadiseyi haber alır almaz bir toplantı düzenleyerek bu hadise hakkında protestoda bulunmak üzere Maarif Vekâletine derin teessürlerini bildiren bir telgraf çekmişlerdir (Cumhuriyet, 1933, s.1).

Düzce Gençler Birliği de, Gazetelere gönderdikleri yazıda, Razgrad hadisesinden dolayı duydukları üzüntüyü dile getirmişlerdir (Cumhuriyet, 
1933, s.2). İstanbul Dişçi mektebinde okuyan 200 kadar Bulgar talebesi de Razgrad hadisesinden çok müteessir olduklarını belirterek iki kardeş milletin münasebetlerini tehlikeye düşüren bu fena hadiselere son verilmesini istemişlerdir (Cumhuriyet, 1933, s.2). Yunanistan'da yapılan tahrikâtı protesto etmiş ve Bulgaristan hükümeti nezdinde Trakya- Bulgar Cemiyetinin icraatını ve hükümetin bunlara karşı gösterdiği kayıtsızlığı eleştirmiştir (Cumhuriyet, 1933, s.1).

Yunus Nadi Razgrad Hadisesi ve Bulgaristan başlıklı yazısında:

“Bulgarların işine karışmayız ama Bulgaristan'da ki Türk unsurların tamamen haksiz ve yersiz muamelelere maruz kalmasına, Türkiye Türk'lerinin lakayt kalamayacaklarını Bulgaristan bilmelidir. Bulgarlar, dünyanın en sakin, en mert ekalliyeti olan Bulgaristan Türklerine sataşmakla kendi lehine değil ancak kendi kendinin aleyhine çalışmış olur" (Cumhuriyet,1933, s.1) İfadelerini kullanmıştır.

Razgrad olayı meclis gündemine de gelmiştir. Mazhar Müfit Bey'in Hariciye Vekâletine yönelttiği soru önergesi, meclis celselerine katılamaması nedeniyle hükümsüz kalmıştır ( TBMM Zabıt Ceridesi, Devre: 4, Cilt:14, İçtima: 2, 1933). Konu, sonrasında meclis gündemine gelmemiştir.

Hâkimiyeti Milliye Gazetesi hükümetçe izin verilmediği halde ve zabıtanın karşı çıkmasına rağmen yapılan bu hareketi; “İstanbul'daki Kanunsuz Hareket Fena Bir Tesir Uyandırdı" başlığıyla yayınlamıştır ve şöyle devam etmiştir:

"Gençlik kalabalığının yaptığı izinsiz ve kanunsuz toplanma efkârı, umumiyemizde fena bir tesir bırakmıştır. Bu kalabalı̆ın üstelik bir de karakol önünde toplanarak bağırıp çağırması, bilhassa nizam ve intizamm en çok hüküm sürmesi lazım gelen bir muhitte böyle bir hareketin yapılması hayret uyandırmıştır" (Hâkimiyeti Milliye,1933, s.1).

Ayrıca bu gibi nümayişleri doğru bulmadıklarının başlıca sebebini şöyle açıklamışlardır: "Bunlarm arasına karışacak, kim oldukları belirsiz, hangi maksada veya yabancı emele hizmet ettikleri gizli olan insanlarm kalabalı̆̆ istenmeyecek bir taşkınlığa sürüklemeleri ihtimalidir. Onun için zabıta kuvvetlerimiz bütün manasıyla tetikli davranmışlar ve Cumhuriyet kanunların dinlemeyenlere karşı ciddi mukavemet göstermişlerdir" (Hâkimiyeti Milliye, 1933, s.1).

Üniversite gençliğinin Türk mezarlığının kasıtlı olarak tahrip edildiğine inanması ve olayı cevapsız bırakmamadaki kararlılığını gören CHP yetkilisi 
onları açık bir dille derneklerini kapatmakla tehdit etmiştir ( Duman ve Yorgancilar, 2008, s.50).

Bulgaristan'daki hadise dolayısıyla talebe tarafından yapılan nümayişin uyandırdığı akis ve MTTB’nin kapatılacağı haberleri üzerine, MTTB Kongre Heyeti toplanarak vaziyeti konuşmuşlardır. Toplanma neticesinde Gazi Hazretlerine, Başbakana birer mektup gönderilmesi, Dâhiliye Vekili Şükrü Kaya Bey'e de bir telgraf çekilmesi kararlaştırılmıştır (Vakit, 1933, s.2).

Telgrafta, Gazi inkılâplarının hediye edildiği gençlerin Razgrad faciasına karşı izhar ettiği temiz hissiyatın yanlış anlaşıldığı, gençliğin daima Gazi yolunda olduğunu tekrarladıkları arz edilmiş ve Talebe Birliğinin kapatılmaması rica edilmiş̧ir (Cumhuriyet, 1933, s.1).

Kongre'nin en ilgi çekici yönü, birlik daimi delegeleri tarafından $22 \mathrm{Ni}$ san 1933 günü Cumhurbaşkanına gönderilen mektubun cevabının gelmiş olması idi. Cumhurbaşkanı Gazi Mustafa Kemal Paşa'nın imzasını taşıyan cevabi telgrafda şu ifadeler yer alıyordu:

“Türk Talebe Birliği Kongresi Daimi Murahaslarına;

Gençliğin çalışkan, hassas ve milliyetçi yetişmesi esas dileklerimizdendir. Gençlik her türlü faaliyetlerinde Cumhuriyet kanunlarına ve Cumhuriyet kuvvetlerinin usul ve kaidelerine riayetkâr bulunmağa da dikkatli olmalıdır. Cumhuriyet hükümetinin milli meselelerde vaziyetini bilir olduğuna, kanunlara ve adli kuvvetlerin adaletine emin olunuz" (Cumhuriyet,1933, 28, Nisan, s.1).

Milli Türk Talebe Birliğinin vaziyetine gelince, Emniyet Müdürlüğünce bu hususta vilayete de resmen müracaat edilmiştir (Vakit, 1933, 22, Nisan, s.2). Birliğin idare heyeti ile bazı azalarının müsaadesiz nümayiş tertip etmek hususunda diğer talebeleri teşvik ettikleri neticesine varılmış ve bu vaziyet karşısında talebe birliğinin kapatılması lazım geldiği ileri sürülmüş ve mesele tetkik edilmeye başlanmıştır (Son Posta, 1933, 23, Nisan, s.6). Birlik hakkında kapatma kararı gündeme gelse de uygulamaya konulmamıştır. 1936 Kasımına kadar yaklaşık 10 yıl faaliyette bulunmuştur. Birlik daha sonraki yıllarda tekrar açlıp kapanarak ve nitelik değiştirerek varlığını uzun yıllar sürdürmüştür ( Şensoy, 1998, s.138).

Müsaadesiz toplantı meselesinden dolayı mevkuf bulunan talebe hakkındaki tahkikat 25 Nisan'da bitmiş, 23 talebenin tutuksuz olarak muhakeme edilmelerine karar verilmiş ve kendileri serbest bırakılmıştır. Bu sırada adliye koridorlarında arkadaşların bekleyen yüzlerce genç, mevkufların 
tahliyesini görünce alkışlarla kendilerini karşılamışlardır (Akşam, 1933, 26, Nisan, s.1).

Davanın hukuki süreci bir süre devam etmiş ve 2335 sayılı Umumi Af kapsamında değerlendirilerek, yargılananlar affa uğramıştır(Çav,2010, s.110). Tutuklu kaldıkları süre içerisinde İstanbul'un birçok pastanesinden pasta ve tatlı gönderildiğini, meşhur lokantaların her gün yemek gönderdiğini belirten MTTB'liler yaptıkları eylemin doğruluğuna sonuna kadar inanmışlardır ( Duman ve Yorgancılar, 2008, s.51). Nitekim birkaç ay sonra Razgrad'da benzer bir hadise yine cereyan etmiştir. Türkiye'nin Sofya Elçiliğinden gelen raporda şu ifadeler yer almaktadır:

Makedonya ihtilalinin yıl dönümüne tesadüf eden 2 Ağustos 1933 günü Demir Baba tekkesi avlusunda çadır kuran Bulgar gençleri türbenin duvarlarını telvis etmekle kalmayarak âlemi kırıp atmışlardır. Bu türbenin zaman zaman uğradığı tecavüzler ve içi kazılarak yapılan iskelet taharriyatı evvelce arzedilmiştir. Deliorman muhitinde 50 senelik bir Bulgar rejiminden sonra hala kendilerini yabancı hisseden Bulgarlar, öçlerini Türk hâkimiyet ve ekseriyyetinin bıraktığı izleri yok ederek almağa çalışmaktadırlar ( BCA,030. 10. 241.630.35).

MTTB kendi yayın organları olan Birlik Gazetesinde Razgrad hadisesinin yıldönümü münasebetiyle "Kara Bir Yıldönümü" başlıklı bir yazı kaleme alarak, atalarını büyük hatıralarını korumak şereflerini yükseltmek için yeminlerini tazelemişlerdir (Birlik, 1934, s.2).

\section{Sonuç}

Gençlik, toplumların geleceğinin bir göstergesidir. Her milletin gençliği, toplumunun fikir, ideal ve ruh yapısını yansıtır ve bunları geleceğe taşır. Gençlik, toplum içerisinde meydana gelen sorunlara en fazla duyarlılı̆̆ gösteren kesim olmuştur. Cumhuriyet döneminde ise özellikle örgütlü hareketleriyle, ulus-devlet inşası noktasında, yürüttüğü faaliyetleriyle ön saflarda yer almış, bu anlamda destekleyici söylem ve eylemler ortaya koymuştur.

Bulgaristan'ın Deliorman bölgesindeki Razgrad kasabasında bir grup Bulgar milliyetçisinin 15 Nisan gecesi Türk mezarlığına saldırması, yurt içinde büyük tepkilere neden olmuştur. Olay'ın Türkiye kamuoyunda duyulmasıyla birlikte, İstanbul başta olmak üzere ülkenin çeşitli illerinde pro- 
testo mitingleri düzenlenmiştir. Oysaki Yurtta sulh cihanda sulh ilkesiyle hareket eden Türkiye, bütün komşularıyla olduğu gibi Bulgarlarla da dost geçinmek için elinden geleni yapmış, Bulgar devlet ricali de aynı düşüncelerle Türk dostluğunun kıymetini takdir etmişlerdir. Fakat yaşanan hadise Bulgar devlet ricali ile Bulgarların düşüncelerinin farklı olduğu gerçeğini yansitmışır.

Bu çirkin hadiseye gençliğin tepkisi de o nisbette büyük olmuştur. Milli Türk Talebe Birliği idare heyeti, bazı talebe teşekkülleri idare heyetleriyle ortak bir toplantı yaparak bu olaya nasıl cevap vermeleri gerektiğini istişare etmişlerdir. Resmi makamlar konu ile hükümetin meşgul olacağını, gayri mes'ul şahıs ve teşekküllerin müdahale etmemesini bildirmişlerdir. Öğrenciler bu ihtara rağmen, izinsiz olarak olayı protesto etmek, aldıkları kararları uygulamak istemişlerdir. 20 Nisan 1933'de gençler beşer, onar kişilik kafileler halinde, Maçka'daki Bulgar Konsolosluğu önünde toplanmağa başlamışlardır. Bu kafile, Polisin müdahalesiyle dağılırken, gençlerin bir kısmı ara sokaklardan Bulgar mezarlığına gitmişlerdir. Öğrencilerin, mezarlığı, misilleme yaparak tahrip edeceği beklenirken, çelenk koyarak karşıllık vermişlerdir. "Bulgarlar bizden insanlık ve medeniyet dersi almalıdır. Biz ölülere hakaret değil, saygı duyarız " diyerek duygularını ifade etmişlerdir. Sonrasında güvenlik kuvvetleri tarafından mezarlıktan çıkarılmışlardır. Ardından Taksim'e doğru yürüyüşe geçmişlerdir. Bütün ihtarlara rağmen gençler yürüyüşlerine devam etmiş, bu olay sonucunda, 80 öğrenci gözaltına alınmıştır. Gösteriler nedeniyle gözaltına alınan 80 öğrenciden 23'ü tutuklanmıştır. Altı gün sonra serbest bırakılan öğrenciler, yargılanmaları sürerken çıkarılan genel aftan yararlanmışlardır. MTTB, "Razgrad Olayı" nedeniyle zaman zaman hükümet ile karşı karşıya gelmiş, hatta yaşanan olaylar nedeniyle birliğin kapatılması dahi gündeme gelse de bu uygulamaya konulmamıştır. 1936 Kasım ayına kadar yaklaşık 10 yıl faaliyette bulunan MTTB, daha sonraki yıllarda tekrar açlıp kapanarak ve nitelik değiştirerek varlığını uzun yıllar sürdürmüştür.

Türk-Bulgar ilişkilerinin daha çok devlet adamları düzeyinde iyi olduğu bu dönemde, yaşanan hadise, Bulgarların hala eski düşünce ve bakış açılarından kurtulamadıklarının da bir göstergesi olmuştur. İnsani bir yaklaşım olamayan bu durumun perde arkasında, yaklaşık 400 yıl Osmanlı yönetiminde kalan Bulgarların bu süreçte kendilerini esir bir millet olarak görmüş olmaları yatmaktadır. Nitekim bu konuya sürekli olarak vurgu yapmışlar- 
dır. Razgrad Olayı aynı zamanda gelecekte yaşanacak olayların habercisi olması noktasında da önemlidir. 1933 yılında Türkiye'nin Sofya Elçiliği'nden gelen raporlarda, Bulgaristan'da yaşayan Türklerin kötü muamelelere maruz kaldıkları ve bunların bir an önce Türkiye'ye naklinin değerlendirilmesi gerektiği üzerinde durulmuştur. Cumhuriyet'in kuruluşundan itibaren devam eden göç dalgası 1991 yılına kadar sürüp gelmiştir.

İki ülke idarecilerinin çabalarına rağmen, Bulgaristan'da yaşayan Türkler, Bulgar milliyetçileri için kolay hedef durumunda olmuşlardır.

"Razgrad Hadisesi" Bulgaristan'da yaşayan soydaşlarımızı ve Türkiye'de yaşayan tüm vatandaşları derinden üzmüştür. Türk kamuoyu ve basını hadisenin üzerine gitmiş, toplumsal bir tepki gösterilmiştir. Bu noktada yaşanlar karşısında gençliğin verdiği tepki ise Türk gençliğinin üstlendiği cumhuriyeti koruma misyonuna emsal teşkil etmiştir. 


\title{
EXTENDED ABSTRACT
}

\section{Ataturk Period Student Movements On The National Press: The Razgrat Event}

\author{
Neslihan Altuncuoğlu \\ Erciyes University
}

Youth is an indicative of the future of societies. Every nation's youth reflects its society's structure of mind, mission, and spirit and carries them into future. Youth became a part which shows the most awarness to the occurrence of events in society. Youth was in the front line with the continuing operations at the point of building nation - state and especially orginised movements in the period of Republic and it presented supportive expressions and actions in this sense.

At the beginning of February in 1934, the foreign affairs ministers of Turkey, Greece, Yugoslavia and, Romania met in Belgrade and they prepared the draft of Balkan Entente. Balkan Entente was established by being signed this entente in Athens in February, 1934. Bulgaria stayed out of entente. While Turkey was making such an effort on the way which went to Balkan Entente, Bulgaria turned up pressures on Turkish minority and Turkish schools were started to close or these schools were turned to national Bulgarian schools in the years of 1930s. In some regions Turkish children could not go to the school or they had to study Bulgarian in national Bulgarian schools. There are many citizens who take refuge from these regions and become Turkish citizen as a result of wrongdoings to our citizens.

In the April of 1933, the event of being attacked to the Turkish graveyard by the members of jingoist Bulgarian organizations in Razgrad town in which Turkish Muslims live intesively and it became a current event for Turkish people and Turkish public opinion. Turkish press which came down to the event behaved very sensible about the issue and tried to inform the public opinion about it.

Turkish youth were into the Works of nation and country from constitutionalism. In the years of First World War and National Struggle, they almost came to the country's rescue. They became members, frank protectors, and diffusers of Turkish Reform. They were into the events which related to 
Turkish people's future. Turkish higher education youth gathered un the same roof of the "National Turkish Student Association" (NTSA) in 1933 when the Razgrad event occured. The year of 1933 became a dynamic year in recognition of youth organization. In this period, nationalist Turkish youth movements became dense ve these nationalist works were managed by national Turkish student association. National Turkish student association handled the subject of language in 1933 and they decided to warn the citizens who lived in Bulgaria by holding a public demonstration and made an effort for dominating only Turkish language in Turkey. Besides, it was decided to prepare a Youth Anthem and to wear monotype flat cap for all students. Turkish youth attended all together to the commemoration of martyrs which was on 16th March 1933 and the president of National Turkish Student Association Teyfik Bey made a speech which exhilarates national feelings.

A group of nationalist Bulgarian attack to the Turkish graveyard at the night of 15th April in Razgrad town which is in the distirct of Deliorman in Bulgaria caused big reactions in the country. By being heard the event in Turkey, indignation meetings were hold in all provinces especially in İstanbul. Whereas,Turkey which acting with the principal of "Peace at home, peace in the World" pulled out all the stops to get on with Bulgaria like other countires and Bulgarian government officers appreciated Turkish friendship with the same feelings. However, the event which is occured reflected that the reality of different thoughts of having Bulgarian people and Bulgarian government officers.

The reaction of youth became according as big as to this dirty event. National Turkish Student Association administrative committee consulted with some student organizations principals how to react to this event by conducting a joint meeting. Official authorities informed that the govenment will be into this subject and not interfere for other responsible people and ogranizations. In spite of this warning, students wanted to make a protest and carry out the decisions which they took. Youth started to gather in front of Bulgarian consulate by the group of five and ten on 20th April 1933. This group was separated by police officers' interference and some of the youth went to the Bulgarian graveyard in the side streets. It was supposed that the students would destroy the graveyard but they replied by placing a wreath. "Bulgarian people should take culture and humanity lessons from us. We 
respect the deads not insult them." They expressed their feelings with these sentences. After that they were exserted from graveyard by the poliçe officers. Then they started to walk to Taksim. In despite off all warnings, the youth continued walking and as a result of this eighty students were interned. Because of the events, 23 of interned students were arrested. Razgrad Event deeply saddened all our citizens who live in Bulgaria and Turkey. Turkish public opinion and press addressed the event and showed a social reaction. The reaction which the youth showed was an example to the proctection of republic mission which was taken on by Turkish youth.

In this study which was performed by survey model, it was presented with a descriptive research in the example of Razgrad Event that the youth which was in the period of republic reflected the reality of the structure of society's mind, mission, and spirit with supportive actions and speeches, with organized movements, and with the continuing operations at the point of building nation - state. In this study, one of the qualitative data acquisition tecniques, document analysis was used, and was examined by desciptive analysis tecnique and it was provided that the readers can use and understand the datas and realibility of this study was increased by quoting. The datas were procured in the study from which was used data collection tool, the sources which are in the archives of Republic of Government of President, the term's newspapers, copyright works about the subject, post graduate thesis.

\section{Kaynakça / References}

Ağca, Ü.( 2014). Türkiye Bulgaristan Iliş̧kileri Çerçevesinde Razgrad Olayı ve Türk Kamuoyuna Yansımaları.Yüksek Lisans Tezi. Nevşehir Hacı Bektaş Veli Üniversitesi Sosyal Bilimler Enstitüsü Tarih Ana Bilim Dalı.

Aksoy, C. ( 1977).Babam Tevfik Ileri Konuşmalan Görüşleri. Ankara: Ayyıldız Matbaası.

BCA, Fon Kodu: 03018, Kutu No: 01002, Dosya Gömleği No:374, Sira No:19.

BCA, Fon Kodu: 03010, Kutu No: 242 Dosya Gömleği No: 635,Sıra No: 17.

BCA, Fon Kodu: 03010, Kutu No: 241, Dosya Gömleği No: 626, Sıra No:15.

BCA, Fon Kodu: 030100, Kutu No: 241, Dosya Gömleği No: 627, Sira No:17.

BCA, Fon Kodu: 03018, Kutu No: 0102, Dosya Gömleği No: 336, Sira No:3.

BCA, Fon Kodu: 03018, Kutu No: 0102, Dosya Gömleği No: 363, Stra No:68.

BCA, Fon Kodu: 03010, Kutu No: 241, Dosya Gömleği No: 627, Sıra No:26.

BCA, Fon Kodu: 03010, Kutu No: 241, Dosya Gömleği No: 628, Sira No:9. 
BCA, Fon Kodu: 03010, Kutu No: 241, Dosya Gömleği No:630,Sıra No: 13.

BCA, Fon Kodu: 03010, Kutu No: 241,Dosya Gömleği No: 630,Sıra No: 8.

BCA, Fon Kodu: 03010,Kutu No: 241,Dosya Gömleği No: 627, Sıra No:2.

BCA, Fon Kodu:03010, Kutu No: 241, Dosya Gömleği No: 627, Sıra No: 26.

BCA, Fon Kodu:03010, Kutu No: 241, Dosya Gömleği No: 630,Sıra No: 35.

BCA, Fon Kodu:03010,Kutu No: 241,Dosya Gömleği No: 629,Sıra No: 2.

BCA, Fon Kodu:3010,Kutu No: 241, Dosya Gömleği No: 630, Sıra No: 2.

Çav, E.(2010).Tanzimat'tan Cumhuriyete Türkiye'de değişen gençlik haraketleri ve Milli Türk

Talebe Birliği Deneyimi (1916-1980). Doktora Tezi. Mimarsinan Güzel Sanatlar

Üniversitesi Sosyal Bilimler Enstitüsü Sosyoloji Anabilim Dalı Genel Sosyoloji ve Metodoloji Programı.

Çavdar, T.(1995).Türkiye'nin demokrasi tarihi 1839-1950. Ankara: İmge Yayınları.

Duman, D ve Yorgancılar, S.( 2008).Türkçülükten İslamcllı̆̆a Milli Türk Talebe Birliği. Ankara: Vadi Yayınları.

Duman, D ve Yorgancılar, S.(2008).Türkçülükten İslamcllığa Milli Türk Talebe Birliği, Ankara: Vadi Yayınları.

Esmer, A.(1953). Siyasi Tarih. Ankara: Siyasal Bilgiler Fakültesi Yayınları.

Goloğlu, M. (2009).Tek Partili Cumhuriyet(1931-1938).İstanbul: Türkiye İş Bankası Kültür Yayınları.

Gönlübol, M ve Sar, C. ( 1963). Atatürk ve Türkiye'nin dış politikası (1919-1938). Ankara: Milli Eğitim Basımevi.

................. (1995). Her yönüyle Tevfik İleri. Ankara: Türkiye Diyanet Vakfi Yayınları.

Kabacalı, A.(1992).Türkiye'de gençlik hareketleri. İstanbul: Altın Kitaplar Yayınevi.

Kara Bir Yıldönümü. (1934,1 Mayı).Birlik,2.

Nesimi, A. (2008). Yilların İçinden. İstanbul: Nöbetçi Yayınevi.

Razgrad Hadisesi Bizde ve Bulgarlarda Uyandırdığı Akisler.(1933, 21 Nisan). Hâkimiyeti Milliye, 1 .

Soysal, İ. ( 1999).Cumhuriyet Döneminde Türk diplomasisi. Ankara: Türk Tarih Kurumu Basimevi.

Şahin, M.( 1992). Darülfünun Talebe Cemiyeti önderliğinde gerçekleştirilen bir öğrenci hareketi örneği. Tarih ve ToplumDergisi. 18(107) .15-22.

Şensoy, T.(1998). Atatürk Dönemi öğrenci olaylarn: 1918- 1938. Yüksek Lisans Tezi. İnönü Üniversitesi Sosyal Bilimler Enstitüsü Tarih Eğitimi Anabilim Dalı.

Şimşir, B. (1986).Bulgaristan Türkleri. (1878-1985).Ankara: Bilgi Yayınları.

Taylak,M. ( 1969). Saltanat II. Meşrutiyet ve I. Cumhuriyete öğrenci hareketleri. Ankara: Başnur Matbaası.

Yazman, A. (1984).Atatürk'le Beraber. İstanbul: Türkiye İş Bankası Kültür Yayınları. 
(1985). Razgrad Olayları. Yeni Türk Ansiklopedisi, İstanbul: Ötüken Yayınlar. 3195.

. (2005). Razgrad olayları. Cumhuriyet Ansiklopedisi:1923-1940. Cilt: 1. İstanbul: Yapı Kredi Yayınları.

Ertürk,S.(2005). Bulgaristan basinnnda Türkiye ve Atatürk (1923-1938).Yüksek Lisans Tezi, Celal Bayar Üniversitesi Sosyal Bilimler Enstitüsü Tarih Anabilim Dalı.

TBMM Zabıt Ceridesi, Devre: 4, Cilt:14, Içtima: 2,1933; TBMM Zabıt Ceridesi, Devre:4, Cilt:15, İçtima:2, 1933.

Evelki Günkü Nümayiş. (1933,22 Nisan). Vakit,1-2.

Nümayiş Tahkikati. (1933,22 Nisan). Cumhuriyet, 1-2

Türk Mezarı Nasıl Yıkıldı. (1933,16 Nisan). Vakit, 2.

200 Bulgar Türk Mezarliğını Yıktlar.( 1933,18 Nisan). Vakit,1.

Türk Mezarlı̆̆ Fena Şekilde Tahrip Edildi.( 1933, 18 Nisan). Cumhuriyet,1.

Türklere Tecavüz Edildi. (1933, 18 Nisan).Son Posta,1.

Razgrad Faciası Derin Bir Teessür Uyandırdı.(1933, 19 Nisan). Cumhuriyet,1.

Türk Mezarı Kimler Tarafindan Yıkıldı. (1933,19 Nisan). Vakit,9.

200 Bulgar Talebe Protesto Ettiler. (1933,20 Nisan). Cumhuriyet, 2.

Yunus Nadi. (1933, 20 Nisan) Razgrad faciası derin bir teessür uyandırdı. Cumhuriyet,1.

Razgrad Faciası Derin Bir Teessür Uyandırdı. (1933,20 Nisan). Cumhuriyet, 1.

Razgrad Tecavüzünü Protesto. (1933,20 Nisan). Hâkimiyeti Milliye,1.

Büyük Nümayiş. (1933, 21 Nisan). Akşam, 2.

Dün Nümayiş Yapılmak İstendi. (1933, 21 Nisan). Milliyet,1.

Muazzam Bir Nümayiş. (1933,21 Nisan). Son Posta, 9.

Talebe Dün Büyük Nümayiş Yaptı. (1933,21 Nisan). Cumhuriyet,1.

Sadık, N. (1933,22 Nisan). Evvelki günkü nümayiş. Akşam,1.

İstanbul'da ki Kanunsuz Hareket. (1933,22 Nisan). Hâkimiyeti Milliye,1.

Daver, B. (1933,22 Nisan) İşte Bulgar dostluğu. Cumhuriyet,1.

Evelki Günkü Nümayiş. (1933, 23 Nisan).Vakit,2.

Hadise Tahkikat Safhasinda. (1933,23 Nisan). Son Posta,6.

Nümayiş Yapan Talebe Adliyeye Verildi. (1933, 23 Nisan). Cumhuriyet,1.

Tevfik Rüş̧ü Bey Bulgar Başvekille Görüştü. (1933,24 Nisan). Cumhuriyet,1.

Razgrad Hadisesi. (1933,25 Nisan). Akşam, 1.

Bulgar Meclisinde.(1933, 26 Nisan). Hâkimiyeti Milliye,1.

Gençler Tahliye Edildiler. (1933,26 Nisan). Cumhuriyet,1.

Müsaadesiz Toplantı Hadisesi. (1933,26 Nisan). Akşam,1.

Büyük Gazi ve Gençlik. (1933,28 Nisan). Cumhuriyet,1. 
Sobranya'da Garip ve Şiddetli Münakaşalar. (1933,28 Nisan). Cumhuriyet,1.

Safa, P. (1933,29 Nisan). Bu Ne Demek ? Cumhuriyet,2.

Bulgaristan'1 Protesto. (1933,30 Nisan). Cumhuriyet,1.

Razgrad Faciası Derin Bir Teessür Uyandırdı. (1933, 30 Nisan). Cumhuriyet, 1..

\section{Kaynakça Bilgisi / Citation Information}

Altuncuoğlu, N. (2021). Ulusal basin ekseninde Atatürk Dönemi öğrenci hareketleri: Razgrad Hadisesi örneği. OPUS-Uluslararası Toplum Araştırmaları Dergisi, 17(33), 701-726. DOI: 10.26466/opus.844644 